\title{
The Hypertopia Option
}

\author{
Mark A. S. McMenamin \\ Department of Geology and Geography, Mount Holyoke College, South Hadley, Massachusetts 01075, United States
}

Copyright $\bigcirc 2019$ by authors, all rights reserved. Authors agree that this article remains permanently open access under the terms of the Creative Commons Attribution License 4.0 International License

\begin{abstract}
The Hypertopia Option, described here, uses the inherent connectivity of the land biota to combat the anthropogenic accumulation of carbon dioxide in the atmosphere. The crux of the proposal is that we must soon establish new towns (Hypertopias) in arid and marginal land areas, with inhabitants hand-nurturing nascent forests until these are sufficiently established to be self-sustaining. Irrigation will be required to initiate Hypertopias, but the need for irrigation will decrease once the Hypertopias are established due to enhancement of rainfall as a function of aforestation. Close attention to and encouragement of hypermarine (that is, associated with Hypersea) symbioses between vascular plants and mycorrhizal fungi will enhance efforts at reforestation. Hypersea theory maintains that the establishment of the land biota in the middle Paleozoic was dependent on such symbioses. Hypertopias will induce localized reestablishment of the land biota, simultaneously generating favorable human habitats, with local economies initially based on caring for the newly established plants, later transitioning to economies based on foods and other forest products that can move us away from plastics and other environmentally deleterious materials. Carefully sited and maintained, Hypertopias promise to rapidly absorb carbon dioxide, leading us to a regime of sustainable and favorable climate.
\end{abstract}

Keywords Hypertopia Option, Hypersea, Carbon Sequestration, Carbon Cycle, Hypermarine Upwelling, Symbiosis, Mutualism, Quail Guzzlers, Global Warming, Global Climate Change

\section{Introduction}

As I write this, temperatures have reached nearly $12^{\circ} \mathrm{C}$ (over $50^{\circ} \mathrm{F}$ ) at the Isfjord Radio Weather Station (Fig. 1), on the island of Spitzbergen, Svalbard, Arctic Norway (A. Werner, pers. comm, 7/30/19). The unmistakable signature of global warming is upon us. Is there anything that can be done in practice to mitigate global warming? To answer this question, we must carefully consider the interaction between human activity (or lack thereof) and global climate.

The reforestation of much of eastern North America, in the wake of the demise of Native American populations (who kept much of the land clear), is hypothesized to have absorbed so much carbon dioxide that it caused the Little Ice Age (LIA, c. $1500 \mathrm{AD}$ ) by regrowth of Neotropical forests sequestering 2-5 $\mathrm{Pg} \mathrm{C}$ in the wake of the Columbian encounter [1]. New calculations suggest [2] that "the planet could support nearly 2.5 billion additional acres of forest without shrinking our cities and farms, and that those additional trees, when they mature, could store . . 200 gigatons of carbon." Further recent estimates suggest that human influence (or its sudden absence) can cool as well as warm global climate. Putting this realization to practical use can mitigate climate change. Could this be accomplished by, far from shrinking our cities and farms, actually expanding towns and farms and thus expanding human habitats while helping the environment? I propose the Hypertopia Option as one method of achieving this.

\section{The Hypersea Substrate}

Hypersea [3-4] represents all eukaryotic organisms on land and their symbionts. Hypersea is defined [4] as a "biogeophysical entity formed by eukaryotic life and its symbionts, parasites and hyperparasites on land." In other words, Hypersea represents the interconnected land biota, counterintuitively dominated by fungi. This is so because of the osmotrophic abilities of mycorrhizal (Fig. 2) and other fungi. By means of the chemistry of osmotrophy, these organisms are able to procure mineral nutrients directly from rock and soil. The key symbiotic nutrient exchange in Hypersea takes place in vascular plant root cells, by means of arbuscles. Arbuscles are bushy, modified fungal hyphae that form inside of vascular plant root cells. Arbuscles resemble microscopic trees. The huge surface area of the tiny arbuscle facilitates nutrient exchange. In this exchange, mineral nutrients are delivered to the plant from the symbiotic fungus, and excess sugars are sent from the plant to the fungus. 


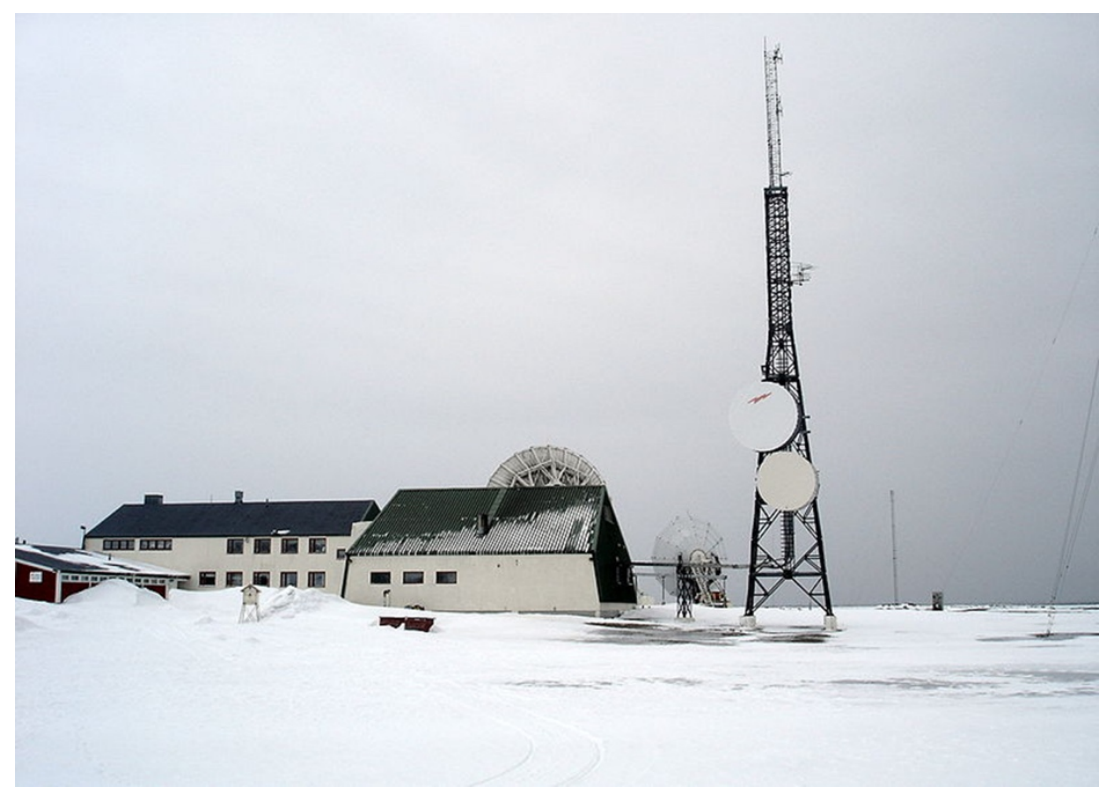

Figure 1. Isfjord Radio Weather Station, Svalbard, Norway. Photo credit: Mikeangelo. Used here per CC BY-SA 3.0

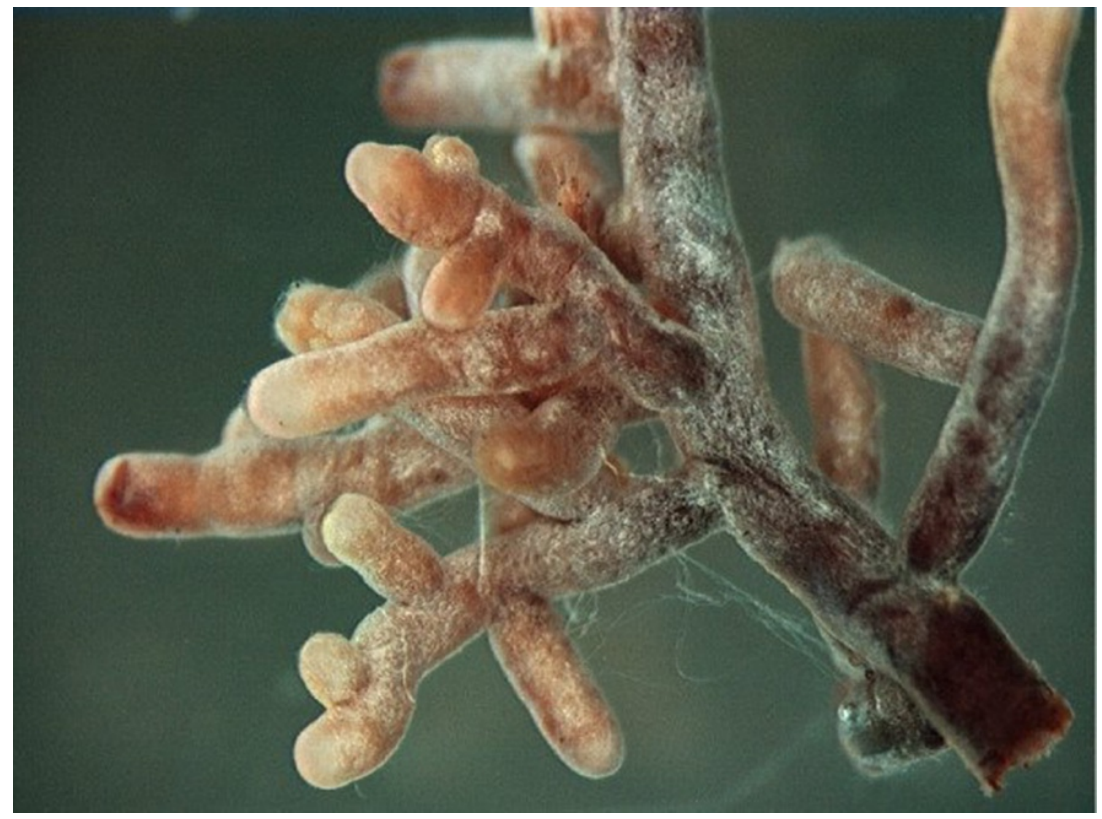

Figure 2. Ectomycorrhizal symbiosis with tree rootlets. Photo Credit: Ellen Larsson. Published Source: R. Henrik Nilsson, E. Kristiansson, M. Ryberg, K.-H. Larsson, 2005, Approaching the taxonomic affiliation of unidentified sequences in public databases-an example from the mycorrhizal fungi, BMC Bioinformatics, Vol.6, 178, doi: 10.1186/1471-2105-6-178. Used here per CC BY 2.5

A variety of fungal species live below ground, and are interconnected with a vast variety of vascular plant species above and below ground. These are all interconnected. Nutrients, for example potassium, may be transported from one end of a forest to the other by symbiotic fungi [5-6]. By means of such fungal transport of nutrients, hypermarine connections between osmotrophic fungi and vascular plants caused the greatest expansion of the biosphere in earth history [3-4]. Global biomass increased by at least two orders of magnitude (100x). This result challenges the conventional Darwinian view of evolutionary change with its focus on individual organisms and competitive interactions. A striking instance of this is the unusual case of the Septobasidium fungus and its insect partner.

In the strange case of the felt fungus Septobasidium, a plant-parasitic scale insect is invested and protected by a lichen-like fungus on the surface of the plant [7]. This leads to a hypermarine fluid transfer as follows. The arbuscles of the soil mycorrhizal fungi pass mineral nutrients to the host woody vascular plant. Nutrients travel up the vascular system of the plant and are intercepted by the suctorial tube of the scale insect. They are then passed to the Septobasidium fungal hyphae, coiled up inside the body of the scale insect. In some cases the insect may also be 
infected by hymenopteran parasitiods. This hypermarine sequence is a microcosm of the Hypertopia Option proposed here, with humans playing an equivalent of the flow-modulating role of the Septobasidium fungus. Many other cases of this type of hypermarine linkage could be cited, the most important of course being the vascular plant-mycorrhizae connection. The trophic influx of the Hypersea phenomenon (especially via hypermarine upwelling, that is, conduction of mineral nutrients to the surface via fungal osmotrophy) is such a powerful biogeophysical force that it has literally altered the geology of planet Earth.

Coal is an unusual type of rock when earth history is considered as a whole. This unique rock type was essentially unknown before the Devonian Period. Thick layers of Pennsylvanian coal occur in Kentucky, USA and elsewhere (c. $323 \mathrm{Ma}$ ), and were deposited in advance of the Permo-Carboniferous glaciation. The first full flourishing of Hypersea withdrew so much carbon dioxide from the atmosphere that it nudged global climate into icehouse conditions, causing a major glacial interval $[8,9]$.

Other examples of presumed carbon cycle perturbations in earth history are well known. The Snowball Earth glaciation interval of Proterozoic age (c. $750 \mathrm{Ma}$ ) is linked to changes in the carbon cycle, for example the growth of giant stromatolites (megascopic domal-to-columnar microbial structures) during the breakup of the supercontinent Rodinia. This led to the worst glaciation in earth history [10]. The great Permo-Triassic mass extinction is linked to carbon cycle perturbation [11] associated with injection of massive amounts of carbon dioxide and toxic mercury into the atmosphere by the Siberian Traps lava flows. This led to the worst mass extinction known in earth history. The Paleocene-Eocene Thermal Maximum (PETM), thought to have been caused by the release of methane by the breakdown of permafrost and sea floor gas hydrates, led to an alarming $6^{\circ} \mathrm{C}$ global temperature increase over roughly 20,000 years [12]. With these examples as cautionary signposts, a key element of humanity's stewardship of the planet would seem to be that we are called to serve a beneficial role as a global thermostat.

\section{The Hypertopia Option}

The demise of native populations during the Columbian exchange was largely due to literally dozens of zoonotic diseases [13] infecting European human populations accustomed to living in close contact with their livestock. A result of this disaster was cessation of hunting grounds management (annual burns) by Native Americans. Blanket reforestation of eastern United States consumed massive amounts of atmospheric carbon dioxide. An apparent consequence of this was Little Ice Age.

In the dry Western USA, relatively wet areas gain more rainfall. In the moist Eastern USA, relatively dry areas gain more rainfall [14]. This is so because the dry areas heat up faster, causing air to rise and drawing in moisture-laden air from surrounding areas, that then rises and cools.

Areas vulnerable to desertification are in a number of cases ripe for (re)forestation [15]. The Little Ice Age and Permo-Carboniferous global cooling are two examples that show that Hypersea can influence global climate. The effect is valid at a variety of timescales: historical time, evolutionary time, geological timescales, etc.

The Caborca region, NW Sonora, México, where I completed my dissertation work in the early 1980s, had vegetation characteristics as follows: cholla-desert, open sandy areas and desert pavement areas. Returning in the mid-1990s, I was intrigued to see that the vegetation had changed noticeably. There was newly dense underbrush, the sage plants were larger, and the flora overall was beginning to look more like that of the El Paso region in Texas. I conclude from this that slight increases in precipitation in desert areas can dramatically and rapidly alter the vegetation cover in arid regions.

The migration crisis in Central America, a situation fraught with political implications for the United States, Mexico and various countries in Central America, has been caused in large measure by climate change and subsequent desiccation of critical regions leading to an inability to grow crops [16]. Application of Hypertopia ecological engineering in Guatemala and other Central American nations could rescue the agricultural productivity of the land, provide a renewed economic base for local populations (Fig. 3), and simultaneously sequester large amounts of carbon.

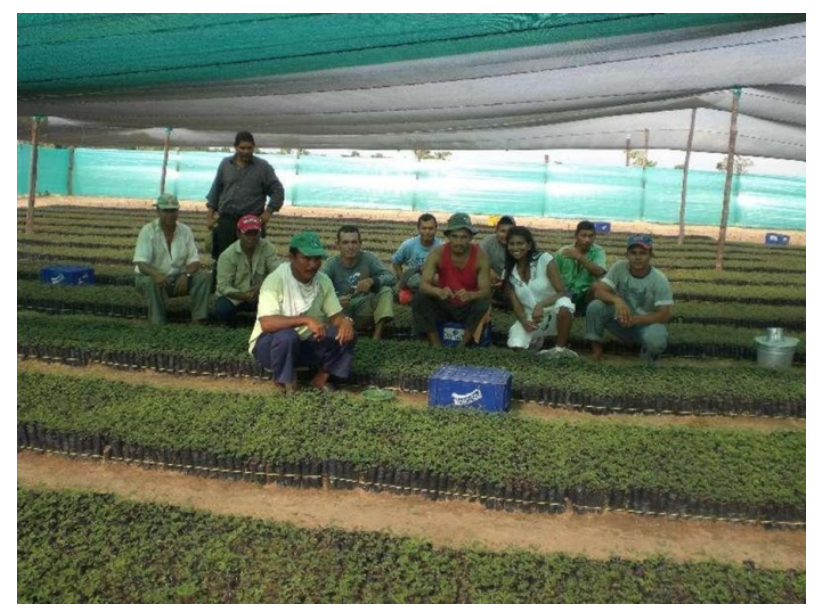

Figure 3. Tropical tree nursery at Green Planet Reforestation (Planeta Verde Reforestación), Vichada, Columbia. Photo Credit: The Ent. Used here per CC BY 3.0

"Bright Spot" coral reefs are those that are doing better than otherwise expected in studies of the global decline of coral reefs. These reefs are improving [17] as "a function of local management ". This includes "active fishery management by local people."

Overfishing and ecological collapse due to coral loss in the Vanuatu archipelago (consisting of about 80 islands) 
has led to disappearance of fish species. Efforts to replant the reefs with "tougher species of corals than those destroyed", similar to efforts in the northeastern United States to preserve syrup-producing maple tree (Acer saccharinum) forests, are yielding beneficial results in terms of greater catches of fish [18].

If newly forested areas are large enough, the trees themselves can induce increased precipitation. The additional precipitation is due to temperature reduction and other factors [19]. Precipitation is most strongly enhanced by new forestation in arid regions [19-21].

British-Palestine colonial governments felt that Palestine had only enough water to support a population of 2 million people. The Negev desert was thought to be "inhospitable to human habitation, a wasteland " [20-21] "Jewish pioneers... recycled pipes that the British had used to put out fires during the Blitz to transport water in the Negev. "The discarded British pipes first used to frustrate Hitler's effort to terrorize the people of London now [assisted] settlement construction," writes Mr. Siegel." [21]

Russian prince and scientist Pyotr Kropotkin (1842-1921) was fascinated during his scientific expeditions to Siberia by his observation that, in order to survive in a hostile environment, organisms must assist one another. In reply to Thomas Huxley's Darwinian essay "The Struggle for Existence," Kropotkin wrote Mutual Aid: A Factor of Evolution (1902). This was an important piece of the ongoing Russian challenge to fallacies of Darwinian evolutionary theory [22]. Kropotkin's conclusion was that community success depends on mutual aid and cooperation among organisms in the face of a challenging physical environment.

Usage of oil and gas is not going to vanish anytime soon. Oil is in many ways a "wunder-fuel" due to its energy-rich chemical makeup [24]. For example, no battery cell (in principle) can ever approach the ounce-for-ounce energy delivery of gasoline. The United States Geological Survey recently announced the Wolfcamp Shale discovery [24] of 20 billion barrels of oil and 16 trillion cubic feet of natural gas (greatest discovery in U.S. history). This represents a big benefit for a petroleum-hungry economy, but for what are its implications for climate? Emphasis here is on the acute need for economically viable carbon sequestration.

\section{Hypertopia in Four Steps}

\section{Step 1}

Identify arid and under-forested regions of the world, such as the Great Basin and Range in the Western United States [14] or the Draa Valley, Morocco [15].

\section{Step 2}

Build quail guzzlers and related structures to capture periodic rainfall [25].

\section{Step 3}

Pipe in water from distant regions (once a more favorable hydrological cycle is locally established, begin exploiting groundwater sources). Desalination potentially also an option.

\section{Step 4}

Combine arid land reforestation project with new human habitat areas (Hypertopia towns and cities), built from the ground up with best available modular technologies (superinsulation, Heat Mirror glass, solar, etc.). Inhabitants hand-nurture the nascent forests until they are well-enough established to be self-sustaining. By necessity, much of the human habitat in Hypertopia will be low-income housing ("green affordable housing").

\section{Global Thermostat}

I served as a water commissioner in District \#2, South Hadley, MA. I learned from this experience that local governments will respond favorably when the situation works in favor of the local populace. A positive attitude of growth helps keep everyone on board. Coercive mandates, especially from foreign or international bodies, are an invitation for conflict and lack of cooperation [26].

Human population growth has been portrayed as an evil since the 1960s-1970s (Paul Ehrlich, Population Bomb, Limits to Growth, etc.). These schemes tended to underestimate planetary carrying capacity. The British-Palestine colonial government mistakenly assumed that Palestine could only support 2 million people [20-21]. It now supports 12 million people. This is a factor of six revision. Hypertopias are going to require a lot of energetic and educated young women and men with active, outdoorsy jobs managing the reforestation project(s) and Hypertopia communities. This new generation will help propel wholesome economic growth and thus will benefit the entire national and global economy.

A purely secular attitude toward planetary restoration courts failure. Hypertopias must include not merely churches and faith communities, but presumably also monasteries and convents. Pope Benedict XVI expressed this theme: "Are not the oases of creation that sprang up, say, around the Benedictine monasteries in the West foreshadowings of this reconciliation of creation brought about by the children of God-just as, conversely, something like Chernobyl is a shocking expression of creation's enslavement in the darkness of God's absence? " [27].

If Hypertopias-nurtured forests become too successful, in accordance with Vladimir Vernadsky's concept of the Pressure of Life, they can be scaled back and deleterious climate forcing avoided by harvesting the timber or otherwise moderating the rate of carbon sequestration. This may seem to be the least of our worries, but recall that there 
is an icehouse disaster scenario (Little Ice Age, Snowball Earth) as well as its torrid alternative (Permo-Triassic, end Triassic, PETM). Hypertopias can provide us the means to nurture symbiosis-supported (and thus resilient) biodiversity [28-29], plus they provide humanity with a throttle we can use to control atmospheric $\mathrm{CO}_{2}$. This can easily offset fossil fuel carbon emissions, so there is no need for unpopular, politically fraught, and economically-disruptive coercive measures. It may at first seem unrealistic to assume that Hypertopias will eventually be able to generate the rain that they require, but a series of recent studies [30-32] indicate that forest establishment can indeed induce rainfall at scales from localized to continent-wide.

\section{Acknowledgements}

Thanks to G. Foley, J. L. Bubier, L. Margulis, D. McMenamin, S. Tuttle and A. Werner for assistance with this research.

\section{REFERENCES}

[1] R. A. Dull, R. J. Nevle, W. I. Woods, D. K. Bird, S. Avnery, W. M. Denevan. The Columbian encounter and the Little Ice Age: Abrupt land use change, fire and greenhouse forcing. Annals of the Association of American Geographers, Vol.100, No.4, 755-771, 2010.

[2] Renkl, M. The trees might save us yet. The New York Times, July 22, 2019, https://www.nytimes/2019/07/22/tre es-global-warming.html.

[3] M. A. S. McMenamin, D. L. Schulte McMenamin. Hypersea: Life on Land, Columbia University Press, New York, 1994.

[4] M. A. S. McMenamin, Schulte McMenamin. Hypersea and the land ecosystem. BioSystems, Vol.31, 145-153, 1993.

[5] M. A. Gorzelak, A. K. Asay, B. J. Pickles, S. W. Simard. Inter-plant communication through mycorrhizal networks mediates complex adaptive behavior in plant communities. AoB Plants, Vol.7, doi:10.1093/aobpla/plv050, 2015.

[6] M. Tlalka, D. Bebber, P. R. Darrah, S. C. Watkinson. Mycelial networks: Nutrient uptake, translocation and role in ecosystems. British Mycological Society Symposia Series, Vol.28, 43-62, 2008

[7] D. A. Henk, R. Vilgalys. Molecular phylogeny suggests a single origin of insect symbiosis in Pucciniomycetes with support for some relationships within the genus Septobasidium. American Journal of Botany, Vol.94, No.9, 1515-1526, 2007.

[8] G. Feulner. Formation of most of our coal brought earth close to global glaciaton. Proceedings of the National Academy of Sciences (USA), Vol.114, No.43, 11333-11337, 2017.
[9] D. J. Beerling. Low atmospheric $\mathrm{CO} 2$ levels during the Permo-Carboniferous glaciation inferred from fossil lycopsids. Proceedings of the National Academy of Sciences (USA), Vol.99, No.20, 12567-12571, 2002.

[10] Y. Goddéris, Y. Donnadieu. Carbon cycling an snowball Earth. Nature, Vol.456, E8, https://www.nature.com/article s/nature07653, 2008.

[11] J. L. Payne, M. E. Clapham. End-Permian mass extinction in the oceans: An ancient analog for the twenty-first century? Annual Review of Earth and Planetary Sciences, Vol.40, 89-111, 2012.

[12] S. Gupta, K. Kumar. Precursors of the Paleocene-Eocene Thermal Maximum (PETM) in the Subathu Group, NW sub-Himalaya, India. Journal of Asian Earth Sciences, Vol.169, 21-46, 2019.

[13] J. S. Marr, J. T. Cathey. New hypothesis for cause of epidemic among Native Americans, New England, 1616-1619. Emerging Infectious Diseases, Vol.16, No.2, 281-286, 2010.

[14] S. E. Tuttle, G. Salvucci. Empirical evidence of contrasting soil moisture-precipitation feedbacks across the United States. Science, Vol.352, No.6287, 825-828, 2016.

[15] A. A. Lamqadem, B. Pradhan, H. Saber, A. Rahimi Desertification sensitivity analysis using MEDALUS model and GIS: A case study of the oases of Middle Draa Valley, Morocco. Sensors, Vol.18, No.2230, doi: 10.3390/ s18072230, 2018.

[16] N. Kristof. 'Food doesn't grow here anymore. That's why I would send my son north.' The New York Times, June 5, 2019.

[17] J. E. Cinner et al. Gravity of human impacts mediates coral reef conservation gains. Proceedings of the National Academy of Sciences (USA), Vol.115, No.27, 6116-6125, 2018.

[18] M. Moses, B. Hauser, C. Cain, D. Crowley, E. O'Neill. Finding a way to combat global climate change, Daily Hampshire Gazette, Vol.232, No.233, A6, 2019.

[19] D. Sheil, D. Murdiyarso. How forests attract rain: An examination of a new hypothesis. BioScience, Vol.59, No.4, 341-347, 2009.

[20] S. M. Siegel. Let There Be Water, Griffin Press, Adelaide, Australia, 2017.

[21] A. Finley. How to make a desert bloom. The Wall Street Journal, Oct. 6, 2015.

[22] R. Kinna. Kropotkin and Huxley. Politics, Vol.12, No.2, 41-47, 1992.

[23] R. K. Bennett. Why gasoline is still king. The American, Dec. 17, 2008, www.aei.org/publication/why-gasoline-is-st ill-king/

[24] J. R. Dancy. From the Drake Well to Santa Rita \#1: The History of the U.S. Permian Basin: A miracle of technological innovation, 3. Oil and Gas, Natural Resources, and Energy Journal, Vol.3, No.5, https://digitalcommons.la w.ou.edu/one/vol3/iss5/3, 2018.

[25] D. J. Delehanty, S. S. Eaton, T. G. Campbell. Mountain 
quail fidelity to guzzlers in the Mojave Desert. Wildlife Society Bulletin, Vol.32, No.2, 588-593.

[26] B. Gilley, D. Kinsella. Coercing climate action. Survival-Global Politics and Strategy, Vol.57, No.2, https://www.tandofline.com/doi/full/10.1080/00396338.20 $15.1026053,2015$.

[27] J. Ratzinger. Jesus of Nazareth-The Infancy Narratives, Libreria Editrice Vaticana, Vatican City, 2012.

[28] A. Pascual-García, U. Bastolla. Mutualism supports biodiversity when the direct competition is weak. Nature Communications, Vol.8, No. 14326, https://www.nature.co $\mathrm{m} /$ articles/ncomms14326, 2018.

[29] L. B. Martínez-García, G. B. De Deyn, F. I. Pugnaire, D. Kothamasi, M. G. A. van der Heijden. Symbiotic soil fungi enhance ecosystem resilience to climate change. Global Change Biology, Vol.23, No.12, 5228-5236, 2017.

[30] A. M. Makarieva, V. G. Gorshkov. Biotic pump of atmospheric moisture a driver of the hydrological cycle on land. Hydrology and Earth System Sciences, Vol.11, 1013-1033, 2007.

[31] J. S. Wright, R. Fu, J. R. Worden, S. Chakraborty, N. E. Clinton, C. Risi, Y. Sun, L. Yin. Rainforest-initiated wet season onset over the southern Amazon. Proceedings of the National Academy of Sciences (USA), Vol.114, No.32, 8481-8486, 2017.

[32] D. Sheil, D. Murdiyarso. How forests attract rain: An examination of a new hypothesis. BioScience, Vol.59, No.4, 341-347, 2009. 